\title{
External Ear Squamous Cell Carcinoma
}

National Cancer Institute

\section{Source}

National Cancer Institute. External Ear Squamous Cell Carcinoma. NCI Thesaurus. Code C6083.

A squamous cell carcinoma that arises from the skin of the external ear. 